\title{
Mikołaj Wojciechowski
}

\section{Charakter działalności gospodarczej Żydów w średniowiecznej Polsce}

W badaniach poświęconych historii Żydów w średniowiecznej Polsce zagadnienia gospodarcze zajmują bardzo ważne miejsce, gdyż są one istotnym czynnikiem pozwalającym zrozumieć położenie i procesy osadnicze ludności żydowskiej. Na samym początku należy zaznaczyć, że charakter działalności gospodarczej Żydów nie był jednorodny, lecz ulegał zmianom. Złożyło się na to wiele czynników. W głównej mierze powinniśmy mieć na względzie istniejącą ówcześnie koniunkturę społeczno-polityczną, stosunek władzy wobec społeczności żydowskiej oraz intensyfikację procesów lokacyjnych wyznawców religii mojżeszowej. Musimy pamiętać, że osadnictwo Żydów było mocno związane z kształtowaniem się działalności gospodarczej. Ze względu na rozciągłość czasową epoki średniowiecza, w swojej pracy pragnę skupić się na wiekach XII i XIII, przedstawiając najważniejsze ówcześnie aspekty aktywności gospodarczej Żydów. Następne wieki przynoszą znaczącą zmianę charakteru ich działalności ekonomicznej, jednak uważam za konieczne nawiązanie w swoich rozważaniach do czasów wcześniejszych, zarysowując kontekst specyficznego rozwoju aktywności ekonomicznej ludności żydowskiej.

Kwestia działalności gospodarczej Żydów była tematem wielu opracowań. Zagadnienie to często stanowiło część składową większych prac poświęconych sprawom ekonomicznym, ale doczekało się także odrębnych studiów badawczych. W pierwszej kolejności warto wymienić pracę Romana Grodeckiego, która przedstawia historię Polski w okresie średniowiecza, a kwestia żydowska stanowi ważny element całego dzieła ${ }^{1}$. Historyk badający sytuację i działalność Żydów ma do dyspozycji całościowe opracowania Ignacego Schipera ${ }^{2}$, Solomona Katza ${ }^{3}$, Maurycego Horna ${ }^{4}$ oraz książkę

R. Grodecki, Polska piastowska, Warszawa 1969.

2 I. Schiper, Studia nad stosunkami gospodarczymi Żydów w Polsce podczas średniowiecza, Lwów 1911; idem, Dzieje handlu żydowskiego na ziemiach polskich, Warszawa 1937.

3 Vide S. Katz, The Economic Life of the Jews, [w:] Jews in the Visigothic and Frankish Kingdoms of Spain and Gaul, Cambridge 1937.

4 M. Horn, Działalność gospodarcza Żydów polskich w średniowieczu na tle rozwoju osadnictwa, „Żydowski Instytut Historyczny” 1983, nr 2-3. 
Hanny Zaremskiej ${ }^{5}$, przy czym ta ostatnia publikacja stanowi syntezę wielu zagadnień dotyczących sytuacji Żydów w średniowiecznej Polsce. Gdy badamy zagadnienia związane $\mathrm{z}$ dziejami ludności żydowskiej na ziemiach polskich, nie tylko ukierunkowane na tematy stricte gospodarcze, lecz także te odnoszące się do położenia Żydów, należy mieć na uwadze nikłą podstawę źródłową, jaką dysponujemy. Jeśli chodzi o elementy egzystencji Żydów z okresu początków państwa polskiego, od czasów Mieszka I, informacje na ten temat, i to w postaci szczątkowej, pochodzą ze źródeł obcych. Były to po prostu opisy geograficzno-podróżnicze, kroniki i roczniki. Dopiero od XII w. możemy zauważyć na większą skalę pierwsze udokumentowane ślady obecności społeczności żydowskiej na ziemiach polskich. Ten rodzaj źródeł dotyczy przede wszystkim aktów normalizujących położenie Żydów, czy to za pośrednictwem przywilejów wydawanych przez książąt, czy różnego rodzaju zakazów. Każdy z wymienionych dokumentów ma ogromną wartość poznawczą dla przybliżenia sytuacji gospodarczej Żydów na przestrzeni wieków średnich.

Już w początkowym okresie średniowiecza Żydzi na szeroką skalę zajmowali się handlem niewolnikami. Wprawdzie pierwsze wzmianki na ten temat nie dotyczą bezpośrednio terenów Polski, ale stanowią istotną poszlakę w zrozumieniu i prześledzeniu kształtujących się szlaków kupieckich. Najwcześniejszą informację o kupcach żydowskich, którzy podróżowali po krajach słowiańskich przedstawił w swojej relacji arabski kronikarz Ibn Kordadbe z lat 854-8746. W źródłach kupcy ci nazywani są Radanitami lub Rodanitami od okolic nadrodańskich, z których pochodzili. Radanici od VII w. do połowy X stulecia byli prawie wyłącznymi pośrednikiami handlowymi pomiędzy zachodnią Europą a wschodem azjatyckim ${ }^{8}$. W późniejszym czasie zostali oni wyparci $\mathrm{z}$ handlu przez rozwijające się we Włoszech miasta kupieckie i jedyną możliwością kontynuowania przez nich działalności stały się prowadzone na lądzie transakcje kupieckie właśnie przez tereny Słowiańszczyzny. Oczywiście, wymieniona aktywność nie była domeną wyłącznie żydowską, ale kupcy żydowskiego pochodzenia są uchwytni w źródłach wczesnośredniowiecznych. Wzmiankują o nich

$5 \quad$ H. Zaremska, Żydzi w średniowiecznej Europie Środkowej: w Czechach, Polsce i na Wegrzech, Poznań 2005.

$6 \quad$ I. Schiper, Dzieje handlu żydowskiego..., s. 2.

7 M. Horn, Działalność gospodarcza Żydów..., s. 73.

8 I. Schiper, Studia nad stosunkami gospodarczymi..., s. 20. 
również kroniki Kosmasa ${ }^{9}$, Thietmara ${ }^{10}$ oraz żywot św. Wojciecha autorstwa Brunona $\mathrm{z}$ Kwerfurtu ${ }^{11}$. Jeśli chodzi o tereny polskie, pierwsza wzmianka na ten temat pochodzi ze świadectwa Abrahama syna Jakuba, lepiej znanego jako Ibrahima Ibn-Jakuba w dziele Al-Bekriego datowanym na 965/966 r. ${ }^{12}$ Będąc na dworze w Pradze, dobrze znał ówcześnie panującą sytuację ekonomiczną w Europie środkowowschodniej, czy to na podstawie własnych spostrzeżeń, czy z opowiadań innych kupców żydowskich. Wysłannik kalifatu kordobańskiego w swojej relacji wspominał o gromadach kupieckich, przemierzających trzy główne szlaki handlowe. W swojej opowieści Ibrahim usytuował również Kraków, który był ważną osadą handlową. To właśnie z tego miasta wędrowali kupcy z Rusi do Pragi i z Czech na Węgry, a także do Bizancjum. Ruch handlowy w Pradze musiał być prowadzony na dużą skalę, skoro niemożność powstrzymania tej działalności stała się przyczyną opuszczenia Czech przez św. Wojciecha. Kraków stanowił więc ważną bazę handlową, pewien łącznik między Wschodem a Zachodem. Nie mamy żadnych informacji, czy istniał tutaj rynek zbytu niewolników. Moim zdaniem jest to mało prawdopodobne, ponieważ to właśnie do Pragi w celu zakupu niewolników przybywały karawany kupieckie, gdyż stanowiła ona główną stację handlową zachodniej Słowiańszczyzny. Gdyby w Krakowie prowadzono handel niewolnikami, wtedy kupcy ze wschodu nie musieliby wędrować specjalnie do państwa czeskiego. Jednak na podstawie wymienionych źródeł, czy to kroniki Kosmasa, czy Thietmara, widzimy, że istniał pewien przedział czasowy, w którym Żydzi cały czas prężnie zajmowali się handlem niewolnikami ${ }^{13}$.

Inną interesującą wzmianką jest sto lat późniejsza relacja Anonima zwanego Gallem. Kronikarz wymienia osobę Judyty, żony księcia Hermana, która

9 Kosmasa Kronika Czechów, tłum. M. Wojciechowska, Warszawa 1968, ks. II, rozdz. 45, s. 299.

10 Kronika Thietmara, tłum. M. Z. Jedlicki, Kraków 2002, ks. VI, s. 147.

${ }_{11} S_{w}$. Wojciecha biskupa i męczennika Żywot drugi napisany przez Brunona $z$ Kwerfuru, red. J. Karwasińska, Warszawa 1962, rozdz. 12, s. 13-15.

12 Relacja Ibrahima Ibn Jakuba z podróży do krajów słowiańskich w przekazie Al-Bekriego, red. T. Kowalski, [w:] Pomniki dziejowe Polski, seria II, t. 1, Kraków 1946.

13 Biskup Thietmar w swojej kronice pod rokiem 1009 zaświadcza, że król Henryk II był niezadowolony z postawy margrabiego Guncelina, który sprzedawał niewolników Żydom. Podobnie Kosmas podaje, że w 1091 r. kupcy żydowscy, posiadający liczne bogactwa, aktywnie prowadzili handel niewolnikami. Na podstawie tych wzmianek widzimy, że w przeciągu niespełna stu lat w Europie Środkowo-Zachodniej rozwijał się taki rodzaj aktywności gospodarczej ludności żydowskiej. 
wykupywała chrześcijańskich niewolników z rąk żydowskich kupców ${ }^{14}$. Judyta zmarła w 1085 r., więc widzimy, że pod koniec XI w. Żydzi cały czas prowadzili swoją działalność. Na podstawie tego fragmentu, możemy także wywnioskować, że sprzedaż niewolników przez Żydów nie była jednorazowym aktem. Zgodnie z kroniką Galla, Judyta nie wykupiła tylko jednego chrześcijanina, ale większą ich liczbę. Co więcej, rodzi się następujące pytanie - czy w Polsce w tym czasie istniały żydowskie skupiska, które prowadziły wspomnianą działalność, czy były to tylko karawany przemierzające terytorium państwa polskiego? Zdaniem Romana Grodeckiego, żydowskich kupców można stopniowo uważać za miejscowy element, lecz nie ma co do tego stuprocentowej pewności. Jak słusznie zauważył ten uczony, w czasach księżnej Judyty, wszechwładny palatyn Sieciech sprzedawał swoich przeciwników w niewolę ${ }^{15}$. Być może istniały wówczas w Polsce osady kupieckie specjalizujące się w handlu niewolnikami, których nabywcami byli właśnie kupcy żydowscy.

Ostatnia wzmianka dotycząca omawianej profesji odnosi się do Przemyśla, w którym zgodnie z responsem Jehudy ben Meira ha-Kohena od początku XI w. istniała osada żydowska ${ }^{16}$. W dziele Sefer ha-dinim przytoczona jest historia dwóch żydowskich braci porwanych podczas najazdu wojsk i następnie sprzedanych $w$ niewolę. Jednak $w$ responsie pojawia się także informacja o pewnym chłopcu, z pewnością nie-żydowskim, który został sprzedany Żydowi jewiańskiemu. Widzimy więc po pierwsze, że gmina żydowska musiała się prężnie rozwijać, skoro mowa o żydowskich dzieciach. Wymieniony jest również starszy Żyd, który zaopiekował się młodszą sierotą. Po drugie, dostrzegalny jest przez cały czas dobrze prosperujący handel niewolnikami prowadzony przez Przemyśl. Tym razem jednak pojawiają się Żydzi wzięci w niewolę. Automatycznie nasuwa się pytanie - jak to możliwe, skoro wielu badaczy zwracało uwagę, że ludność żydowska nabywając niewolników musiała być jednocześnie wolna? Chciałbym zaprezentować własne stanowisko $w$ tej kwestii. Na podstawie tych fragmentarycznych informacji można zauważyć, że dwaj bracia nie byli przeznaczeni na sprzedaż niewolniczą, ale po prostu zostali pojmani podczas ataku nieprzyjaciół. Wprawdzie zostali uprowadzeni z miasta, wkrótce jednak napastnicy ich pozostawili. Doszło więc do zbrojnego najazdu wroga, czego konsekwencją było pojmanie Żydów. $Z$ redakcji Sefer ha-dinim wynika również, że osobą zabraną w niewolę

14 Anonima tzw. Galla Kronika, czyli Dzieje książąt i władców polskich, red. K. Maleczyński, Kraków 1952, ks. II, rozdz. 1, s. 66.

15 R. Grodecki, Polska piastowska..., s. 607.

16 T. Lewicki, Źródła hebrajskie i arabskie do dziejów Przemyśla, Przemyśl 1932, s. 54-56. 
był stary Żyd, który potem zaopiekował się sierotą. Jeśli chodzi natomiast o drugi przypadek, chłopiec sam zaświadczył, że został porwany w Przemyślu, a następnie wysłany do Pragi, gdzie stał się własnością wspomnianego bizantyńskiego Żyda. Tutaj nie widzimy żadnego łupieżczego ataku. Można więc postawić następujący wniosek: Żydzi zostali pojmani w niewolę jako jeńcy wojenni w charakterystyczny dla tamtych czasów sposób, a mianowicie ze związanymi rękoma. Natomiast dziecko zostało schwytane w celach sprzedaży niewolniczej i wysłane do Pragi.

Nie można się zgodzić $\mathrm{z}$ twierdzeniem Schipera, ażeby wraz z początkiem XIII w. ostatecznie zanikł handel niewolnikami ${ }^{17}$. Widoczny jest on w XII, a także w XIII w. Dla XII stulecia informacje na ten temat pochodzą z taryfy celnej dla Pomiechowa ${ }^{18}$, natomiast dla roku 1226 poświadczone są przez taryfę komory dla Oleśna i Siewierza ${ }^{19}$. W obydwu przypadkach wymienieni są niewolnicy jako artykuł handlowy. Co więcej, na podstawie zeznań naocznych świadków kupcy żydowscy przekraczający komory uiszczali opłatę celną na równi z chrześcijanami, a oprócz wozów ze śledziami i solą przewozili również niewolników. Z biegiem czasu, od schyłku XIII w., znikają wiadomości o żydowskich handlarzach niewolnikami na ziemiach polskich.

$\mathrm{Na}$ samym początku swojej pracy wspomniałem, że działalność gospodarcza Żydów na ziemiach polskich nie miała charakteru stałego. Wraz z początkiem XIII w. widzimy zmianę w dotychczasowej strukturze ekonomicznej społeczności żydowskiej. Handel żydowski przybrał inny kierunek, zmieniły się uczęszczane przez kupców żydowskich szlaki handlowe ${ }^{20}$. Przemiany $\mathrm{w}$ stosunkach handlowych wiążą się z rozwojem miast $\mathrm{w}$ środkowo-zachodniej Europie. Magistraty miejskie już od końca XII w. stawały się coraz bardziej niezależne, a kupca obcego uważały za konkurencję. Jednak początkowa słabość mieszczan cały czas umożliwiała egzystencję żydowskiego handlu na ziemiach polskich. Z przytoczonej taryfy celnej z Siewierza wynika, że Żydzi przed rokiem 1226 prowadzili handel dalekosiężny, ale także detaliczny. W świetle tego dokumentu, jak było to wspomniane wcześniej, społeczność żydowska i chrześcijańska płaciła taką samą wysokość opłaty, natomiast miejscowi kupcy chrześcijańscy oraz żydowscy, wcale nie musieli wnosić opłaty za przejazd od cła pieszego i konnego ${ }^{21}$. Widzimy więc, że na

\footnotetext{
I. Schiper, Studya nad stosunkami gospodarczymi..., s. 27.

R. Grodecki, Polska piastowska..., s. 609.

19 Kodeks dyplomatyczny Śląska, t. 3, nr 309, s. 114-116.

20 I. Schiper, Dzieje handlu żydowskiego..., s. 10.

21 R. Grodecki, Polska piastowska..., s. 622-623.
} 
terenie Śląska Żydzi prowadzili handel lokalny, skoro mowa w dokumencie o miejscowych kupcach żydowskich, poruszających się pieszo. Druga przytoczona przeze mnie wzmianka dotyczy pierwszego wydanego przez księcia wielkopolskiego, Bolesława Pobożnego, spisu praw dla Żydów w 1264 r. ${ }^{22}$ Ostatni paragraf statutu kaliskiego odnosi się właśnie bezpośrednio do handlu detalicznego i zgodnie z jego treścią Żydzi mogli swobodnie sprzedawać i kupować różne produkty. Na podstawie tego aktu możemy stwierdzić, że również w Wielkopolsce musiały istnieć w tym czasie większe skupiska ludności żydowskiej, trudniącej się handlem lokalnym. Przywilej gwarantował Żydom bezpieczny handel i prawo prowadzenia operacji kredytowych. O tym, że żydowska działalność handlowa była dla chrześcijan korzystna świadczy fakt, że już w 1267 r., czyli raptem trzy lata po ukształtowaniu się prawodawstwa wobec starozakonnych, na synodzie we Wrocławiu legat papieski, biskup Gwidon, wydał uchwałę zakazującą kupowania chrześcijanom rzekomo zatrutego mięsa i innych produktów od żydowskich kupców. Jest to bardzo ciekawa informacja, która sugeruje, że Żydzi musieli sprzedawać mięso na dużą skalę, skoro ten artykuł spożywczy został wymieniony w aktach. Oprócz handlu lokalnego, kupcy żydowscy prowadzili cały czas handel dalekosiężny. Dostrzec to można w sposobie płatności kaliskich Żydów na miejsce pod ich cmentarz ${ }^{23}$. W dokumencie czytamy, że ludność żydowska uiszczała stałą opłatę 9 talentów pieprzu i 2 szafranu, dzięki prowadzonemu przez nich handlowi wschodniemu ${ }^{24}$. Początek XIV w. to moment diametralnej zmiany charakteru działalności ekonomicznej Żydów. Wtedy to bowiem kupiectwo chrześcijańskie w sojuszu z cechami wywalczyło pierwsze ograniczenia w działalności handlowej Żydów. Społeczność żydowska została ostatecznie wyparta $\mathrm{z}$ handlu detalicznego na rzecz patrycjatu miejskiego i mogła tylko prowadzić handel zagraniczny ${ }^{25}$. I rzeczywiście, kontakty międzynarodowe są w czternastowiecznych źródłach jak najbardziej widoczne. Warto tutaj wymienić choćby wydany w 1327 r. przywilej dla Sącza, który zwalniał Żydów, przywożących towary na jarmark z Węgier, od płacenia cła $^{26}$, czy dokument zakazujący wszelkiego handlu żydowskiego na terenach należących do zakonu krzyżackiego, wystawiony w 1309 r. przez wielkiego

22 Kodeks dyplomatyczny Wielkopolski, t. 1, nr 605, s. 563-566.

23 Dzieje Żydów w Polsce. Wybór tekstów źródłowych XI-XVIII wiek, red. P. Fijałkowski, Warszawa 1993, s. 42.

24 I. Schiper, Dzieje handlu żydowskiego..., s. 13.

25 M. Horn, Działalność gospodarcza Żydów..., s. 78-79.

26 I. Schiper, Studia nad stosunkami gospodarczymi..., s. 67-68. 
mistrza Seyfridta von Feuchtwangena ${ }^{27}$. Pierwszy akt nie budzi kontrowersji, ponieważ uwidacznia stosunki handlowe ze Wschodem. Drugi natomiast stanowi ciekawe świadectwo egzystencji kupców pochodzenia żydowskiego na terenach krzyżackich, skoro wielki mistrz nagle zdecydował się na przerwanie ich działalności gospodarczej. Warto w tym miejscu wspomnieć o jeszcze jednej ciekawej rzeczy. W 1442 r., w Toruniu i Nieszawie, doszło do rozmów dyplomatycznych między stroną polską a krzyżacką. Dyplomacja polska zażądała wówczas, aby Żydzi mieszkający na ziemiach państwa polskiego mogli swobodnie prowadzić handel na terenach zakonu krzyżackiego $^{28}$. Widać więc, że handel żydowski w Prusach Wschodnich musiał być bardzo intensywny, a przede wszystkim intratny, skoro sami Polacy ubiegali się o zatwierdzenie tego postulatu.

Do tej pory przedstawiłem zajęcia, które w głównej mierze związane były z ciągłym przemieszczaniem się żydowskich kupców. Kolejna działalność gospodarcza Żydów związana była już tym razem ze stałym osadnictwem i specyfiką procesów lokacyjnych na ziemiach polskich. Chodzi mi tutaj o pracę na roli. W badaniach poświęconych kierunkom przybycia ludności wyznania mojżeszowego na ziemie polskie przyjęło się twierdzenie, że wędrujący z zachodu żydowscy kupcy byli elementem ulotnym i tworzyli pierwszą fazę osadniczą. Druga była skoncentrowana wokół przybyszów chazarskich, trudniących się rolnictwem. Jednocześnie uważano, że profesja, którą się trudnili, związana z ziemią, automatycznie wiązała ich ze stałym osadnictwem. Co ciekawe, wszystkie istniejące źródła dotyczą terenów Śląska. Najpierw warto wymienić akt z końca XII w., mówiący o wsi Tyniec, która została nabyta przez wojewodę Piotra Własta od samych Żydów ${ }^{29}$. Podobna sytuacja widoczna jest $\mathrm{w}$ dokumentach trzebnickich ${ }^{30}$. Wspomniana jest w nich wieś Sokolniki, którą posiadali dwaj Żydzi, Józef i Chaskiel. Bardzo interesującą koncepcję na ten temat wysunął Roman Grodecki ${ }^{31}$. Jego zdaniem, w pierwszej kolejności wieś stanowiła osobisty rezerwat dla książęcych sokolników, następnie nabyli ją wspomniani Żydzi, a w ostateczności w 1203 r. stała się ona własnością Henryka Brodatego. Nie wiadomo, kiedy dokładnie Józef i Chaskiel kupili wieś od Wratysława oraz jak długo była ona

I. Schiper, Dzieje handlu żydowskiego..., s. 13.

28 M. Broda, Żydowscy lekarze w państwie Zakonu Krzyżackiego w Prusach w późnym średniowieczu, „Kwartalnik Historii Żydów” 2011, t. 240, nr 4, s. 435.

29 Kodeks dyplomatyczny Śląska, t. 1, nr 68, s. 158.

30 Ibidem, nr 103, 107, s. 249.

31 R. Grodecki, Polska piastowska..., s. 610-611. 
w ich posiadaniu. Źródła milczą w tej sprawie. W 1297 r. klasztor cysterski w Henrykowie na Śląsku kupił u Żyda Merklina z Ziębic wieś Czesławice ${ }^{32}$. Na podstawie tych trzech podanych przykładów możemy wywnioskować, że przedstawiciele społeczności żydowskiej przez pewien okres byli właścicielami wspomnianych dóbr, a posiadając wieś musieli zajmować się uprawą rolniczą w celu zapewnienia sobie utrzymania i bytu. Co więcej, Żydzi występują w tych dokumentach jako ludność wolna. Tylko ludzie o takim statusie społecznym mogli mieć niewolników, rozporządzać ziemią na własność, a także nabywać i sprzedawać dobra osobom stojącym na tym samym szczeblu w hierarchii społecznej. Widać również, że Żydzi byli postrzegani jako równi partnerzy w transakcjach handlowych, skoro nabywcami terenów $\mathrm{z}$ ich rąk byli wysoko postawiony rangą szlachcic i klasztor cysterski, reprezentujący duchowieństwo. Natomiast jeśli chodzi o Sokolniki, to nie sądzę, aby książę Henryk Brodaty bezpośrednio wykupił wieś od Żydów. Z pewnością informacja na ten temat byłaby dostrzegalna w aktach. Kończąc już omawianie działalności rolniczej ludności żydowskiej, warto przytoczyć jeszcze jedno ciekawe źródło, które ostatecznie potwierdzi wysoką pozycję, jaką w stosunkach ekonomicznych od XIII w. zajmowała społeczność żydowska. W świetle dokumentu z 1226 r., dotyczącym wyroku sądu polubownego między Henrykiem Brodatym a biskupem wrocławskim Wawrzyńcem w sprawie dziesięciny kościelnej w kasztelani bytomskiej ustalono, że chłopi książęcy będą płacić dziesięcinę w postaci miodu, natomiast Żydzi i wolni ludzie - dostarczać kościołowi pełną opłatę snopową ${ }^{33}$. Trudno wywnioskować, dlaczego Kościół katolicki zobowiązał wyznawców innej religii do uiszczania należności. Według R. Grodeckiego, w pierwszej kolejności kasztelania znajdowała się w rękach chrześcijan, a następnie Żydów. Mimo to biskup wrocławski nie chciał utracić dochodów z tych ziem. W każdym razie ponownie widzimy, że społeczność żydowska była uznawana za równą ludności wolnej.

Działalność handlowa Żydów łączyła się nierozerwalnie z operacjami kredytowymi ${ }^{34}$. Pierwsze wzmianki na ten temat $\mathrm{w}$ większej skali pojawiają się na zachodzie Europy już w XI w. W Polsce rozwój kredytu żydowskiego przypadł dość późno, ponieważ pierwsze informacje o lichwiarskiej profesji zawiera dopiero statut kaliski. Pożyczanie pieniędzy na procent było zabronione chrześcijanom przepisami kościelnymi ${ }^{35}$. Prawodawstwo wobec

32 Ibidem, s. 627-628.

33 Ibidem, s. 612.

34 M. Horn, Działalność gospodarcza Żydów..., s. 79.

35 R. Grodecki, Polska piastowska..., s. 648-649. 
Żydów - w świetle przywileju Bolesława Pobożnego - zostało wydane, jak już zasygnalizowałem wcześniej, w celu ustalenia ostatecznych warunków prowadzenia charakterystycznej dla ludności żydowskiej działalności gospodarczej: handlu i lichwy. To właśnie z działalnością kredytową powiązany został stereotypowy obraz Żyda-lichwiarza, oczywiście o zabarwieniu pejoratywnym. Jednak to ówczesne warunki społeczno-gospodarcze spowodowały, że jedynym możliwym zajęciem stało się pożyczanie na procent. Żydzi w jakiś sposób musieli egzystować, a jedynym wyjściem była zabroniona przez Kościół katolicki lichwa. W istniejącym systemie feudalnym, w którym posiadanie ziemi związane było ze służbą wojskową i stosunkami senioralno-wasalnymi, Izraelici stopniowo byli odsuwani od działalności produkcyjnej ${ }^{36}$. Wczytując się w treść statutu kaliskiego, wzorowanego na wcześniejszych dyplomach - austriackim (1244), węgierskim (1251 i 1256) i czeskim (1254 i 1255) - widzimy, że operacje kredytowe zajmowały ważne miejsce, skoro odnosi się do nich aż 13 artykułów, a tylko 2 paragrafy dotyczą handlu. Co ciekawe, w przywileju księcia wielkopolskiego nie jest określona wysokość lichwy, jak ma to miejsce w akcie Fryderyka Bitnego z 1244 r. Żydzi bardzo często, za przykładem zachodniego prawodawstwa, są w źródłach określani jako servi camerae - słudzy skarbu. Samo to określenie było terminem technicznym dla określenia prawnego położenia warstwy żydowskiej ${ }^{37}$. Być może w statucie celowo nie ustalono procentu kredytu, ponieważ w pewien sposób stanowiło to cenne źródło dochodów dla samego księcia. W Polsce władcy mocno interesowali się czynszami i kredytami żydowskimi. Dlatego więc, podczas ustalania norm prawnych dotyczących lichwy, ogromną wagę przykładano do zabezpieczenia pożyczek żydowskich ${ }^{38}$. U Żydów pożyczali wszyscy, zarówno władcy, dostojnicy świeccy i duchowni, właściciele ziemscy, mieszczanie, a czasem nawet chłopi ${ }^{39}$. Sama sytuacja społeczna była bardzo korzystna dla rozwoju lichwiarskiej działalności Żydów, ponieważ już od XIII w. widzimy zarysowujące się coraz mocniej konflikty między mieszczaństwem a szlachtą, mające podłoże ekonomiczne. Magistraty odsuwały społeczność żydowską od wszelkich prób handlu detalicznego i operacji kredytowych, natomiast szlachta wolała pożyczać właśnie od Izraelitów. Warto zwrócić uwagę na jedną istotną kwestię, która ukazuje specyfikę położenia Żydów na ziemiach polskich. O ile ich współwyznawcy na Zachodzie zostali

36 H. Zaremska, Żydzi w średniowiecznej Europie Środkowej..., s. 60.

37 I. Schiper, Stydya nad stosunkami gospodarczymi..., s. 41.

38 Ibidem, s. 72-73.

39 H. Zaremska, Żydzi w średniowiecznej Europie Środkowej..., s. 62-63. 
odcięci od jakichkolwiek zajęć gospodarczych i byli zmuszeni do zajęcia się wyłącznie lichwą, o tyle w Polsce, do końca wieków średnich, obok udzielania kredytu mogli parać się również innymi zajęciami. Jednak z biegiem czasu nasilał się ciągły opór szlachty i duchowieństwa przeciwko operacjom kredytowym, doprowadzając często do wystąpień antyżydowskich i pogardy dla prowadzonej przez Izraelitów działalności. Pożyczając coraz częściej i więcej, szlachta zadłużała się u Żydów. W lichwie dostrzegała zatem wszelkie zło, próbę ograbienia chrześcijan z majątków. Również i Kościół katolicki pożyczał u Żydów wysokie sumy, które ciągle się powiększały. Dlatego duchowieństwo rozpoczęło akcję skierowaną przeciwko żydowskiej lichwie, uważając ją za haniebną i nieczystą. Tworzono nowe ustawy państwowe i kościelne, które miały zminimalizować kredytową działalność starozakonnych. Pierwsze ograniczenia wysokości lichwy na ziemiach polskich widoczne są w statucie małopolskim Kazimierza Wielkiego z 1347 r. W świetle tego dokumentu, Żydom nie wolno było pobierać większej lichwy niż $1 \frac{1}{2}$ grosza od grzywny na tydzień ${ }^{40}$. Jednak działalność kredytowa była cały czas prowadzona, czego doskonałym przykładem jest rozwijająca się od połowy XIV w. działalność żydowskich bankierów: Lewki, syna Jordana (będącego osobistym bankierem Kazimierza Wielkiego, Ludwika Węgierskiego, Jadwigi i Władysława Jagiełły) oraz innych krakowskich Żydów, Josmana i Smerlina ${ }^{41}$. Oprócz nich, w samym Krakowie swoją działalność pożyczkową sprawowali również pomniejsi lichwiarze. Bankierstwo żydowskie, w mniejszym stopniu, rozwijało się także w Wielkopolsce, w Poznaniu i Kaliszu, oraz na Mazowszu $^{42}$. Widzimy więc, że mimo pewnych ograniczeń, Żydzi cały czas zajmowali się lichwą, tworząc bankierskie rodziny, będące na usługach przyszłych władców Polski.

W niniejszej pracy przedłożyłem czytelnikowi pewien zarys dotyczący działalności gospodarczej Żydów w średniowieczu. Oczywiście, każdy omawiany przeze mnie aspekt mógłby zostać rozszerzony, a nawet stać się osobnym tematem badawczym. Zwracając uwagę na kwestie ekonomiczne ludności żydowskiej, musimy mieć na względzie, że charakter żydowskiej gospodarki nigdy nie był jednorodny. Jak wykazałem, to od ówcześnie istniejącej sytuacji zależał kierunek działalności gospodarczej. We wczesnych wiekach średnich intratny handel niewolnikami, którego szlaki przebiegały

40 I. Schiper, Stydya nad stosunkami gospodarczymi..., s. 79-80.

${ }_{41}$ Żydzi w średniowiecznym Krakowie. Wypisy źródłowe z ksiąg miejskich krakowskich, oprac. B. Wyrozumska, Kraków 1995, nr 48, 54, 57, 59, 99, 105, s. 30-41.

42 M. Horn, Działalność gospodarcza Żydów..., s. 80. 
przez państwo polskie, stworzył sieć powiązań handlowych między Zachodem a Wschodem oraz możliwość coraz intensywniejszego rozwoju osadnictwa żydowskiego na ziemiach polskich. Wtedy Żydzi zaangażowali się w prowadzenie hurtowej i detalicznej działalności handlowej, a następie zajęli się również lichwą. Wszystko to ukształtowało specyfikę gospodarki miejscowych Izraelitów. Całościowe spojrzenie na problem aktywności gospodarczej Żydów pomoże zrozumieć procesy lokacyjne oraz sytuację prawno-ekonomiczną tej społeczności na ziemiach polskich w średniowieczu.

\section{Bibliografia}

\section{Źródła}

Anonima tzw. Galla Kronika, czyli Dzieje książąt i władców polskich, red. K. Maleczyński, Kraków 1952.

Dzieje Żydów w Polsce. Wybór tekstów źródłowych XI-XVIII wiek, red. P. Fijałkowski, Warszawa 1993.

Kodeks dyplomatyczny Ślaska, t. 3, red. K. Maleczyński, Wrocław 1964.

Kodeks dyplomatyczny Wielkopolski, t. 1, red. I. Zakrzewski, Poznań 1877.

Kosmasa Kronika Czechów, tłum. M. Wojciechowska, Warszawa 1968.

Kronika Thietmara, tłum. M. Z. Jedlicki, Kraków 2002.

Relacja Ibrahima Ibn-Jakuba z podróży do krajów stowiańskich w przekazie AlBekriego, red. T. Kowalski, [w:] Pomniki dziejowe Polski, seria II, t. 1, Kraków 1946.

Św. Wojciecha biskupa i męczennika Żywot drugi napisany przez Brunona $z$ Kwerfuru, red. J. Karwasińska, Warszawa 1962.

Żydzi wśredniowiecznym Krakowie. Wypisy źródłowe z ksiag miejskich krakowskich, oprac. B. Wyrozumska, Kraków 1995.

\section{Opracowania}

BRODA M., Żydowscy lekarze wpaństwie Zakonu Krzyżackiego w Prusach w późnym średniowieczu, „Kwartalnik Historii Żydów” 2011, t. 240, s. $435-443$.

GRODECKI R., Polska piastowska, Warszawa 1969.

HORN M., Działalność gospodarcza Żydów polskich w średniowieczu na tle rozwoju osadnictwa, „Biuletyn Żydowskiego Instytutu Historycznego” 1983, nr 2-3 (126-127).

KATZ S., The Economic Life of the Jews, [w:] idem, Jews in the Visigothic and Frankish Kingdoms of Spain and Gaul, Cambridge 1937.

LEWICKI T., Źródła hebrajskie i arabskie do dziejów Przemyśla, Przemyśl 1932. 
Mikołaj Wojciechowski

SCHIPER I., Dzieje handlu żydowskiego na ziemiach polskich, Warszawa 1937.

SCHIPER I., Studya nad stosunkami gospodarczymi Żydów w Polsce podczas średniowiecza, Lwów 1911.

ZAREMSKA H., Żydzi w średniowiecznej Europie Środkowej: w Czechach, Polsce i na Wegrzech, Poznań 2005. 